\title{
IMPLEMENTASI METODE BERCERITA TERHADAP KEMAMPUAN MEMBACA PERMULAAN ANAK BERKESULITAN BELAJAR MEMBACA
}

\author{
Rosika Novia Megaswarie \\ Pendidikan Luar Biasa, Fakultas Ilmu Pendidikan, IKIP PGRI Jember \\ Email: Itsme.chika@gmail.com
}

\begin{abstract}
Abstrak
Penelitian ini dilatabelakangi oleh kemampuan membaca permulaan pada anak berkesulitan belajar membaca belum berkembang dengan optimal. Anak masih mengalami kesulitan dalam mengenal simbol huruf dan membaca suku kata. Tujuannya adalah untuk mengetahui implementasi metode bercerita terhadap kemampuan membaca permulaan pada anak berkesulitan belajar membaca. Metode penelitian yang digunakan adalah metode deskriptif dengan pendekatan kualitatif. Subyek penelitian ini merupakan anak berkesulitan belajar membaca dengan menggunakan teknik pengumpulan data berupa observasi dan tes lisan. Hasil analisis data menunjukkan adanya perkembangan kemampuan membaca permulaan setelah diberikan intervensi menggunakan metode bercerita. Hal ini dibuktikan dengan anak mampu mengenal simbol, membedakan bunyi kata dalam bacaan, dan mencocokkan gambar dengan tulisan. Penelitian tersebut membuktikan bahwa implementasi metode bercerita berpengaruh terhadap kemampuan membaca permulaan terhadap anak berkesulitan belajar membaca.
\end{abstract}

Kata kunci: Membaca permulaan, anak berkesulitan belajar membaca

\section{PENDAHULUAN}

Pendidikan merupakan sarana pembelajaran yang bertujuan agar peserta didik yang mampu menguasai, mengembangkan, dan memanfaatkan ilmu pengetahuan dan teknologi. Proses pendidikan bagi setiap peserta didik tidaklah sama, bahkan di dalam satu kelas pun meskipun pembelajaran yang dilakukan sama, proses penerimaan mereka tidaklah sama. Hal ini disebabkan karakteristik setiap peserta didik berbeda.

Adanya perbedaan tersebut menyebabkan gaya belajar mereka juga berbeda. Keadaan seperti ini yang menjadikan guru atau tenaga kependidikan untuk lebih kreatif dan inovatif dalam melaksanakan proses belajar mengajar, agar peserta didik tidak kesulitan menerima materi yang diajarkan.

Pendidikan

hendaknya dilaksanakan secara menyeluruh dan dilakukan sejak dini, termasuk pada anak berkesulitan belajar membaca. Menurut Supartini (2001, hlm. 18) anak berkesulitan belajar merupakan anak yang mengalami hambatan dalam hal akademik yang disebabkan oleh banyak faktor. Hambatan tersebut menyebabkan hasil belajar maupun prestasi belajar anak tidak sesuai dengan standar yang ditentukan.

Kesulitan belajar tidak selalu disebabkan faktor kognitif atau kecerdasan anak yang di bawah ratarata. Bisa saja disebabkan oleh faktor lingkungan yang kurang mendukung 
terhadap kemampuan anak, sehingga anak mengalami keterlambatan dalam mengikuti pembelajaran.

Kesulitan belajar yang terjadi pada anak biasanya tampak ketika anak tersebut mengikuti pembelajaran yang berhubungan dengan akademik dasar, seperti membaca, menulis, dan berhitung. Selain itu juga tampak adanya gangguan bicara dan berbahasa (Wardani, 1995, hlm. 7).

Anak berkesulitan belajar dibagi menjadi beberapa, salah satunya anak berkesulitan belajar membaca atau disebut juga disleksia.

Pada anak disleksia, mereka mengalami kesulitan dalam pengenalan simbol atau tanda yang berkaitan dengan huruf. Hal ini terjadi karena tahapan membaca tidak dilalui dengan semestinya.

Disleksia merupakan suatu sindrom kesulitan membaca yang disebabkan kesulitan memahami dan mengintegrasikan komponen kata dan kalimat, serta kesulitan mempelajari segala sesuatu yang berkaitan dengan waktu, arah, dan masa (Bryan and Bryan dalam Abdurrahman, 2003, hlm. 204).

Pembelajaran untuk anak berkesulitan belajar membaca yang dilakukan sejak dini dapat membantu mereka untuk meminimalisir hambatan yang terjadi selanjutnya. Hal ini bertujuan untuk mengembangkan pendidikan di jenjang lebih tinggi. Pada siswa usia dini, kemampuan membaca yang belum berkembang dikhawatirkan akan menghambat kemampuan yang lainnya. Apalagi dalam pendidikan formal untuk anak usia dini saat ini siswa sudah dituntut untuk mampu membaca. Tujuannya untuk mempersiapkan mereka agar tidak tertinggal materi pembelajaran di sekolah selanjutnya.

Membaca permulaan merupakan tahap awal dalam belajar membaca. Fokus dari membaca permulaan adalah mengenal simbol atau tanda yang berkaitan dengan huruf-huruf sehingga menjadi pondasi agar anak dapat melanjutkan ke tahap membaca selanjutnya (Aulia, 2011, hlm. 36).

Perkembangan kemampuan membaca pada anak secara khusus, berlangsung dalam beberapa tahapan (Tale dan

Salzby dalam Dhieni, 2008, hlm. 317), antara lain:

1. Tahap Fantasi (Magical Stage)

2. Tahap Pembentukan Konsep Diri (Self Concepts Stage)

3. Tahap Membaca Gambar (Bridging Reading Stage)

4. Tahap Pengenalan Bacaan (Takeoff reader Stage)

5. Tahap Membaca Lancar (Insependent Reader Stage)

Pada anak disleksia, pembelajaran membaca permulaan sangat penting diajarkan, mengingat kondisi objektif siswa yang belum mampu membaca merupakan tantangan bagi guru di sekolah. Memberikan layanan pendidikan yang kreatif dan inovatif merupakan salah satu cara untuk membantu anak berkesulitan membaca dalam mengembangkan kemampuan membacanya. Namun, kenyataannya tidak sedikit cara tersebut belum memberikan hasil yang signifikan. Salah satu penyebabnya adalah karakteristik siswa yang berbeda.

Berdasarkan hasil temuan di lapangan, siswa cenderung asal mengucapkan kata pada saat diminta membaca. Siswa juga belum mampu 
mengidentifikasi huruf dalam setiap kata yang ditunjuk. Dia juga menunjukkan respons yang tidak suka ketika guru meminta untuk membaca.

Cenderung lebih tertarik dengan gambar daripada huruf, dan juga lebih senang mendengarkan cerita bergambar disertai gerakan daripada mengeja kata.

Selain permasalahan yang terjadi pada siswa, metode yang digunakan guru dalam pembelajaran anak berkesulitan belajar membaca masih menggunakan metode lama. Metode mengeja tanpa modifikasi masih sering digunakan, padahal untuk saat ini, mengeja saja pada kenyataannya membuat anak mudah merasa bosan dan cenderung ingin segera melakukan kegiatan lain daripada kegiatan membaca, sehingga kemampuan membaca mereka belum berkembang dengan optimal.

Berdasarkan kondisi objektif tersebut, diperlukan pembelajaran yang lebih kreatif dan inovatif untuk mengembangkan kemampuan membaca permulaan anak berkesulitan belajar membaca. Salah satu pembelajaran yang kreatif dan inovatif dapat dilakukan dengan menggunakan metode bercerita. Metode bercerita yang digunakan dapat dimodifikasi berdasarkan kreativitas guru dan kebutuhan setiap anak.

Kegiatan bercerita merupakan salah satu cara yang ditempuh guru untuk memberi pengalaman belajar agar anak memperoleh penguasaan isi cerita yang disampaikan lebih baik (Depdiknas, 2006, hlm. 6). Metode bercerita memudahkan setiap orang untuk menyampaikan dan memperoleh informasi. Selain itu juga melatih anak untuk berkomunikasi dengan lingkungan sekitar.

Tujuan metode bercerita menurut Mudini dan Purba (2009) (dalam Agusniatih\&Jane, 2019), antara lain:

1. Mendorong atau menstimulasi seseorang (pendengar) untuk memberikan respons tentang informasi yang diperoleh

2. Meyakinkan orang lain terhadap informasi yang telah disampaikan, sehingga mempengaruhi pendapat yang akan disampaikan oleh lawan bicara. Meyakinkan orang lain juga harus dilakukan dengan menunjukkan bukti, jadi, tidak hanya sekadar cerita saja

3. Menggerakkan orang lain atau pendengar untuk melakukan suatu tindakan. Tindakan tersebut berupa persetujuan maupun argument

4. Memberikan informasi kepada orang lain tentang suatu kejadian atau isu-isu yang saat ini sedang terjadi

5. Metode bercerita juga bertujuan untuk menghibur pendengar melalui informasi atau cerita yang disampaikan, sehingga pendengar merasa rileks, nyaman, dan tenang

Dalam penelitian ini, metode bercerita bertujuan untuk memberikan pembelajaran yang sesuai dengan karakteristik anak berkesulitan belajar membaca, sehingga kemampuan membaca permulaan mereka mampu berkembang dengan baik. Metode bercerita diajarkan dengan menggunakan buku cerita yang sesuai dengan pilihan siswa agar siswa tidak mudah bosan. 


\section{METODE PENELITIAN}

Penelitian ini menggunakan metode deskriptif yang hasilnya berupa data kualitatif. Metode deskriptif bertujuan untuk mengungkap data-data di lapangan yang bersifat aktual mengenai kondisi objektif di lapangan yang berupa kemampuan membaca permulaan pada anak berkesulitan belajar membaca usia dini. Dalam menggali data mengenai kondisi tersebut, digunakan instrumen observasi dan tes mengenai kemampuan membaca permulaan pada anak berkesulitan belajar membaca. Data yang sudah terkumpul dianalisa untuk mengetahui kemampuan membaca permulaan pada anak berkesulitan belajar membaca, yang kemudian dijadikan dasar untuk memberikan layanan pendidikan yang sesuai dengan kebutuhan dan karakteristik anak tersebut.

Penelitian ini dilakukan di Laboratorium Pendidikan Luar Biasa IKIP PGRI Jember dengan subyek penelitian anak berkesulitan belajar membaca. Teknik pengumpulan data yang digunakan adalah observasi dan tes dengan menggunakan instrumen penelitian berupa pedoman observasi yang terstruktur dan instrumen tes berupa tes lisan.

Menurut Prastowo (2010, hlm. 25), kemampuan seseorang untuk melakukan pengamatan melalui sistem pengindraan dibantu dengan panca indra lain dan menggunakan hasil kerja sistem indra tersebut disebut dengan observasi. Observasi dilakukan untuk mengamati dan mencatat pelaksanaan pembelajaran membaca permulaan pada anak berkesulitan belajar membaca di sekolah.
Teknik pengumpulan data dalam penelitian ini selain observasi adalah tes. Tes merupakan alat yang dipergunakan untuk mengukur pengetahuan atau penguasaan obyek ukur terhadap seperangkat konten dan materi tertentu (Djalli dan Muljono, 2008, hlm. 6).

Dalam penelitian ini, tes dilakukan untuk mengetahui kemampuan membaca permulaan pada anak berkesulitan belajar membaca. Tes yang digunakan berupa tes lisan. Anak diminta untuk membaca kata yang sudah disediakan. Waktu yang digunakan dalam pelaksanaan tes ini selama 60 menit.

Data yang diperoleh dari penelitian, dianalisa menggunakan teknik analisa data secara kualitatif. Analisa data secara kualitatif antara lain reduksi data, penyajian data dan penarikan kesimpulan. Dalam mereduksi data yang diperoleh, dilakukan seleksi data, penentuan fokus, penyederhanaan, peringkasan dan mengubah bentuk data mentah yang diperoleh dari lapangan. Setelah data direduksi, data disajikan.

Pada penelitian ini, penyajian data dilakukan secara naratif, dengan mengolah data yang diperoleh dari hasil observasi dan tes berupa penjabaran. Penyajian data yang telah didukung oleh data-data yang baik, dapat disimpulkan menjadi data yang kredibel. Jika belum memberikan simpulan yang berarti, maka perlu mencari data-data yang terkait dengan kekurangan data yang masih belum terpenuhi. Proses ini berlangsung berulang-ulang hingga sampai pada penarikan simpulan yang lebih tepat. 


\section{HASIL DAN PEMBAHASAN}

Penelitian ini berfokus pada kondisi objektif mengenai kemampuan membaca permulaan anak berkesulitan belajar usia dini masih belum berkembang dengan optimal. Berdasarkan kondisi objektif tersebut, diberikan solusi sebagai upaya untuk memberikan layanan pendidikan yang sesuai dengan melakukan pembelajaran membaca permulaan melalui teknik bercerita pada anak berkesulitan belajar usia dini.

Secara garis besar, temuan di lapangan diuraikan dalam skema di berikut ini:

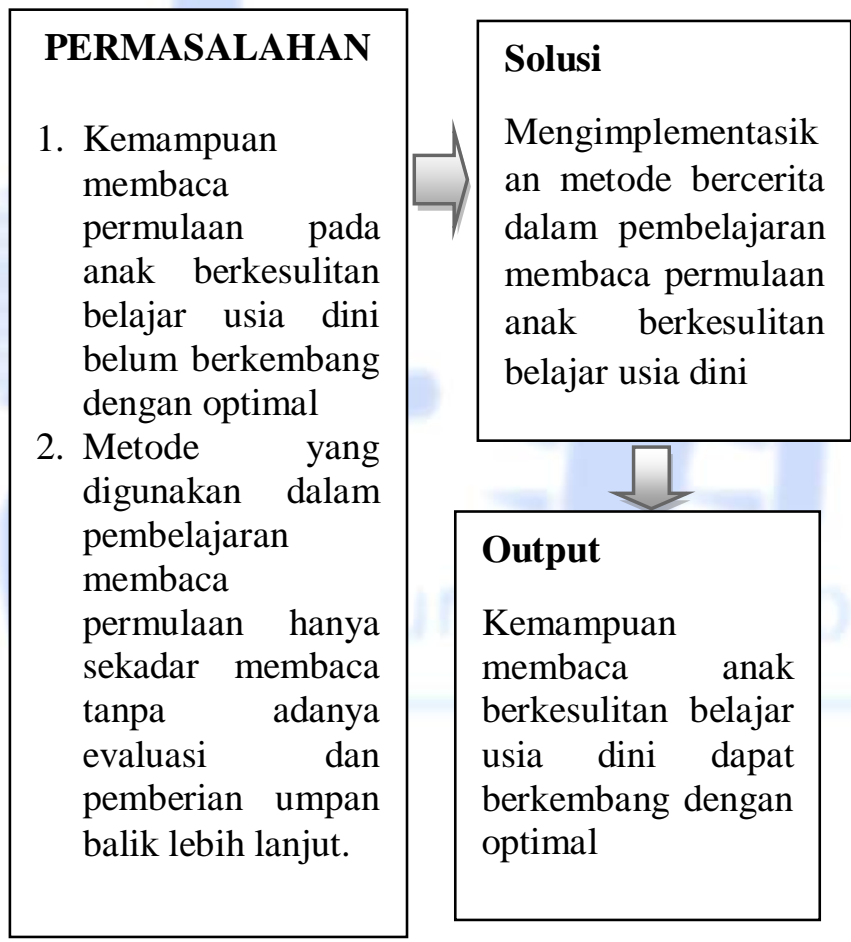

Skema 1. Gambaran umum kondisi objektif di lapangan

Pengumpulan data pada penelitian ini menggunakan teknik observasi dan tes. Observasi dan tes yang dilakukan pada saat pembelajaran seperti biasa bertujuan mengumpulkan data mengenai kemampuan membaca permulaan pada anak berkesulitan belajar usia dini. Hasil observasi dan tes tersebut digunakan sebagai dasar pembuatan program pembelajaran yang sesuai, juga sebagai dasar pemilihan metode dan media yang memudahkan anak dalam belajar membaca.

Sementara observasi yang dilakukan pada saat pembelajaran adalah observasi mengenai penggunaan metode bercerita dalam pembelajaran membaca. Pada saat proses pembelajaran berlangsung, peneliti meminta anak untuk memilih buku cerita yang akan dibaca. Kemudian memberikan apersepsi dengan bertanya mengenai buku cerita tersebut. Selanjutnya, mengenalkan anak pada tokoh yang ada dalam cerita melalui gambar yang terdapat pada buku tersebut.

Observasi dilakukan mulai dari pemilihan buku cerita yang dilakukan oleh anak, alasan anak memilih buku tersebut, sampai hal terakhir anak mampu membaca buku cerita tersebut sampai selesai.

Observasi yang dilakukan dalam penelitian ini adalah observasi terstruktur dengan menggunakan instrumen yang telah disusun berdasarkan indikator-indikator keberhasilan yang ditetapkan. Dari hasil observasi tersebut diperoleh data bahwa terdapat perubahan kemampuan membaca permulaan setelah metode bercerita diimplementasikan dalam pembelajaran membaca permulaan. Anak mampu menerjemahkan atau membaca gambar dengan 
mengidentifikasi dan menggambarkannya. Anak juga mampu mengidentifikasi persamaan dan perbedaan suara yang didengarkan, mencocokkan antara suara, gambar, dan tulisan.

Pengumpulan data dalam penelitian ini selain menggunakan observasi juga menggunakan tes. Tes yang digunakan adalah tes lisan yang sudah disusun berdasarkan indikator-indikator yang telah ditetapkan. Dalam pelaksanaan tersebut, anak diminta anak untuk bercerita dengan penggunaan bacaan sederhana.

Berdasarkan hasil tes lisan tersebut, anak lebih mudah mengidentifikasi perbedaan suara dan menerjemahkannya dalam kata. Anak juga mampu mencocokkan gambar dengan kata yang sesuai kemudian membacanya.

Hasil penelitian ini direkomendasikan untuk dilakukan program selanjutnya dalam mengajarkan anak berkesulitan belajar membaca dalam mengikuti pembelajaran selanjutnya. Hal ini dilakukan untuk mempermudah anak dalam membedakan bunyi huruf, mengidentifikasi kata maupun kalimat, mencocokkan gambar dengan tulisan dalam pembelajaran membaca lanjutan. Pembelajaran dengan metode bercerita ini juga memudahkan guru dalam mengajarkan anak berkesulitan belajar membaca untuk mengembangkan kemampuan membacanya. Guru dapat memodifikasi pembelajaran dengan metode bercerita ini sesuai dengan kreativitasnya masing-masing. Selain itu, guru juga hendaknya memperhatikan kondisi anak sebelum memulai pembelajaran membaca. Faktor lain yang mendukung pembelajaran dengan metode bercerita ini adalah ekspresi yang ditampilkan dalam bercerita. Oleh karena itu, kemampuan berekspresi juga hendaknya dimiliki, sehingga anak mudah dalam menerima pembelajaran dan tidak merasa bosan.

\section{PENUTUP}

\section{Simpulan}

Berdasarkan analisa data dengan menggunakan teknik triangulasi, diperoleh simpulan bahwa metode bercerita berpengaruh terhadap kemampuan membaca permulaan pada anak berkesulitan belajar membaca. Hal ini dibuktikan dengan adanya perkembangan kemampuan membaca permulaan pada anak. Anak mampu mengidentifikasi bunyi atau suara. Selain itu anak mampu mencocokkan gambar dengan tulisan dalam suatu bacaan. Pembelajaran membaca permulaan dengan metode bercerita ini juga dapat dimodifikasi sesuai dengan kreativitas guru.

\section{Saran}

Seorang tenaga pendidik tidak hanya berkewajiban untuk memberi materi pada anak didiknya, tetapi juga dituntut untuk melakukan inovasi dalam pembelajaran sesuai dengan kreativitas dan karakteristik anak, sehingga memudahkan anak dalam menerima materi pembelajaran. Untuk anak berkesulitan belajar membaca, guru dapat menggunakan metode bercerita dalam proses pembelajarannya. Guru dapat melakukan modifikasi sesuai dengan 
kebutuhan anak dan kreativitas masing-masing.

\section{DAFTAR PUSTAKA}

Agusniatih, Andi dan Jane M. Monepa. 2019. Keterampilan Sosial Anak Usia Dini. Tasikmalaya: Edu Publisher.

Aulia. 2011. Mengajarkan Balita Anda Membaca. Yogyakarta: Intan Media.

Depdiknas. 2006. Pedoman Pembuatan Cerita Anak untuk Taman Kanak-kanak. Jakarta: Balai Pustaka.

Djalli dan Pudji Muljono. 2008. Pengukuran dalam Bidang Pendidikan. Jakarta: Grasindo.

Nainggolan, Dewi, dkk. 2017. Pengaruh Metode Fernald
Terhadap Kemampuan Membaca Permulaan Pada Anak Kelompok A Di Paud Mekar Sari Penarik Mukomuko. Potensia: Jurnal Putensi PG-PAUD FKIB UNIB, 2(I), hal. 71-78.

Nurbiana, Dhieni, dkk. 2008. Metode Pengembangan Bahasa. Jakarta: Pusat. Penerbitan Universitas Terbuka.

Prastowo, Andi. (2010). Menguasai Teknik-Teknik Koleksi Data Penelitian Kualitatif. Jogjakarta: DIVA Press.

Supartini, E. 2001. Diagnostik Kesulitan Belajar dan Pengajaran Remidial. Yogyakarta: FIP UNY.

Wardani, IG.A.K. 1995. Pengajaran Bahasa Indonesia bagi Anak Berkesulitan Belajar. Jakarta: Depdikbud DIKTI. 